\title{
Porcine Parvovirus
}

\author{
André Felipe Streck ${ }^{1 *}$ and Uwe Truyen ${ }^{2}$
}

${ }^{1}$ Veterinary Diagnostic Laboratory, Faculty of Veterinary Medicine, University of Caxias do Sul,
Caxias do Sul, Brazil.
${ }^{2}$ Institute for Animal Hygiene and Veterinary Public Health, Faculty of Veterinary Medicine,
University of Leipzig, Leipzig, Germany.
${ }^{*}$ Correspondence: afstreck@ucs.br

https://doi.org/10.21775/cimb.037.033

\begin{abstract}
Porcine parvovirus (PPV) is considered the main cause of reproductive disorders in pigs, which are summarized under the acronym SMEDI (stillbirth, mummification, embryonic death, and infertility). In this review the biology of the virus and its structure, pathogenic potential and strain variation, as well as the disease induced by the virus, are described. Known aspects of pathogenesis, diagnosis and prevention, particularly by vaccination, are summarized. Furthermore, in recent years 'new' parvoviruses (PPV2 to 7) have been described in pigs. They have been detected in pigs from various parts of the world and their association with clinical signs or disease will be discussed.
\end{abstract}

\section{Introduction}

Porcine parvovirus (PPV) is a small non-enveloped virus considered to be one of the major causes of reproductive failure in swine worldwide. Historically, the reproductive losses in commercial swine herds were high in the 1960s, and, at that time, they were associated with environmental, nutritional, genetic and toxicological problems (Lawson, 1961; Rasbech, 1969). The first evidence of porcine parvovirus was obtained in primary cell cultures from porcine kidney and testicle used to cultivate hog cholera virus, where persistent contaminant small particles (22-23 nm size) were found (Mayr and Mahnel, 1964). These particles were similar to the Kilham rat virus (a parvovirus) (Mahnel, 1965). Due to the replication ability of the virus in cell lines from swine, it was possible to isolate and classified as a porcine parvovirus (Siegl 1976).

The occurrence of PPV in pigs was first described by Cartwright and Huck (1967) and was associated with abortions. In the following years, PPV was identified as the main agent of recurring oestrus, abortion and the delivery of mummified or stillborn fetuses, commonly described by the acronym SMEDI (stillbirth, mummification, embryonic death and infertility). The virus is considered to be endemic in most areas of the world and can be found in all pig herd categories. Reproductive losses are typically low in vaccinated herds, but PPV 
can cause devastating abortion storms in unvaccinated herds, in situations in which the vaccine was administered incorrectly or in the emergence of new antigenic types (Truyen and Streck, 2012).

Taxonomically, according to the last release of the International Committee on Taxonomy of Viruses (ICTV), the virus is a member of the family Parvoviridae, Parvovirinae subfamily and Ungulate protoparvovirus 1 species.

\section{Molecular biology of the virus}

The genome all of parvoviruses represents a single stranded (ss) DNA molecule of about $5 \mathrm{~kb}$. In both terminal sequences of the virus, a complex palindromic hairpin structure of about $120-200$ bases is located as requirement for DNA replication. The genome of PPV encodes four proteins and uses alternative splicing to extend the coding capacity. Two nonstructural proteins, NS1 and NS2, operate in the replication of the virus, particularly for DNA replication. Two structural proteins (VP1 and VP2) are transcribed and translated from the parvovirus genome. The smaller protein (VP2) is produced by splicing from the same RNA template as the larger protein (VP1), therefore VP1 has 729 amino acid residues, of which 120 form an amino-terminal unique portion (absent in VP2). The third structural protein, VP3, is a post-translational modification product of VP2 (Simpson et al., 2002; Cotmore and Tattersall, 2006). Additionally, a late non-structural protein (SAT) expressed from the same mRNA as VP2 is found seven nucleotides downstream of the VP2 start codon (Zádori et al., 2005).

As shown in Fig. 6.1, PPV capsid is a spherical shell (with about $28 \mathrm{~nm}$ in diameter consisting) of 60 identical copies of these viral proteins arranged in an icosahedral symmetry (Chapman and Rosmann, 1993). The identical copies (called subunits) are built from about $90 \%$ of VP2 and 10\% of VP1 molecules. (Simpson et al., 2002). The subunit consists of eight antiparallel $\beta$-strands, a common structure for viral capsids, together with one $\alpha$-helix and four loops (Chapman and Rossmann, 1993). On the surface, a projection at the 3 -fold axis, a depression or canyon around the 5-fold axis and a dimple on the 2 -fold axis of symmetry
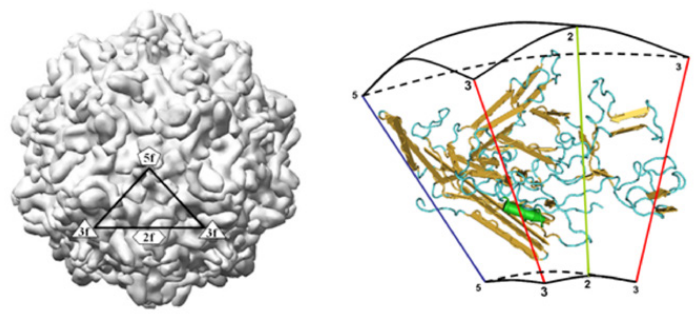

Figure 6.1 The capsid structure of the PPV. Left figure: Surface representations of the capsid calculated from X-ray coordinates with a low pass filter at $17 \AA$ in a temperature factor of $500 \AA$. Right figure: 3D model of the PPV VP2 proteins using the cartoon technique, with a rocket (a-helix) and arrows ( $\beta$-strands) representing the secondary structure. The image was generated with the software Cn3D version 4.1. The coordinates of both figures were retrieved from the NCBI Structure Database (http://www.ncbi.nlm.nih.gov/Structure/index.shtml). Accession number: 1K3V (Simpson et al., 2002). The neighbouring 5- (in blue), 3- (in red) and 2 -fold (in green) axes of the capsid subunit are shown. 
can be observed. The 2- and 3-fold axes consist mainly of amino acids located in the subunit loops (Simpson et al., 2002).

\section{Cellular biology of the virus (including cell tropism, virus-cell interactions, cellular death, etc.)}

The primary replication of the PPV occur in lymphoid tissues. After that, the virus is distributed systemically via viraemia (Paul et al., 1980). It is still not understood how the PPV crosses this placental barrier and reaches the fetus, since six tissue layers completely separate the sow and the fetal blood circulation and these cells are closely connected, not allowing the passage of even small molecules as antibodies, (Mengeling, 2000). Probably, as the virus is able to remain infectious after phagocytosis by macrophages, it can cross the porcine epitheliochorial placenta using macrophages to infect the fetus (Paul et al., 1979).

After fetal infection, the PPV has an environment particularly susceptible to infection and to replication due to the high mitotic activities present in the fetuses' tissues. PPV entrance in a cell is still unclear, but include clathrin-mediated endocytosis, or micropinocytosis transportation mediated by the endosomal pathway (Boisvert et al., 2010). Endosomal trafficking and acidification are essential for PPV to enter in the nucleus (Boisvert et al., 2010), due to reversible modifications of the capsid allowing the virus to escape from the endosome (Vihinen-Ranta et al., 2002; Farr et al., 2005). After the virus arrives in the nucleus, PPV replicates using the cell's own replication mechanism. The virus replicates in cells in replication phase (S) using the cellular DNA polymerase. This explains the requirement for cells with a higher replication index (Rhode, 1973). PPV replication decreased mitochondrial membrane potential and the subsequent oxidative damage also leads to the release of cellular toxic proteins such as cytochrome $\mathrm{c}$ from the mitochondria to the cytosol, triggering apoptosis and causing cell death and tissue damage in viral diseases (Zhao et al., 2016).

The virulence properties of the PPV appear to be related to the viral protein gene. In vitro studies using recombinant viruses derived from pathogenic (Kresse) and non-pathogenic (NADL-2) PPVs showed that single amino acids in the capsid protein affected an isolate's capacity to replicate in certain cell lines. Furthermore, a comparison between Kresse and NADL-2 genomes showed that the non-coding regions were nearly identical. For the nonstructural gene region (NS1/NS2), all differences found are silent (synonymous), while in the structural genes (VP1/VP2) six of eight differences led amino acid substitutions (nonsynonymous). Among the VP2 amino acids, five changes were consistent with comparisons in field isolates (I-215-T, D-378-G, H-383-Q, S-436-P, and R-565-K) and three of these (D-378-G, H-383-Q and S-436-P) were considered responsible for differences in tissue tropism (Bergeron et al. 1996). The amino acid position 436 is located right in the 3 -fold spike centre of the capsid subunit and the amino acid position 215 at its base. This location in the 3-fold spike has been considered to be an important antigenic surface region in various parvoviruses (Chapman and Rossmann 1993).

In the recent viral sequences obtained, it was found that substitutions were mainly located in the capsid surface, therefore influencing the receptor binding and/or antigenicity (Streck et al., 2015a). This could be evident observing the neutralization activities of sera raised against two recent German field isolates by the experimental infection of pregnant sows at day 40 of gestation. The post-infection sera of these sows were tested for their homologous and heterologous neutralization activities. All the antisera demonstrated a 
high neutralization activity against the homologous viruses, but lower activity against the prevalent field strain in Germany (27a) (Zeeuw et al., 2007). Thereafter, studies observed strains closely related to the 27 a strain in several countries and it was estimated that the main divergences between the new isolates were probably introduced in the last 10-30 years (Cadar et al., 2011; Streck et al., 2011). Those findings lead to the hypothesis that the emergence and predominance of '27a-like' strains could be a viral adaptation to the largely used vaccines resulting in 'escape mutants' (Fig. 6.2).

\section{Clinical and pathological observations}

The major clinical sign of PPV infections is maternal reproductive failure reproductive failures. Diarrhoea and skin lesions were also linked to PPV; however, the aetiological role of the virus remains to be fully established (Brown et al., 1980; Dea et al., 1985; Duhamel et al., 1991). Subclinically, a moderate and transient lymphopenia, independent of sex and age, can be observed between 5 and 10 days after initial infection (Joo et al., 1976; Mengeling and Cutlip, 1976; Zeeuw et al., 2007).

Pathological sequela caused by PPV is related mainly to the gestational period in which infection occurs. At the gestation beginning, the conceptus is protected by the zona pellucida and is not susceptible to infection. Thereafter in the stage of embryo (until approximately day

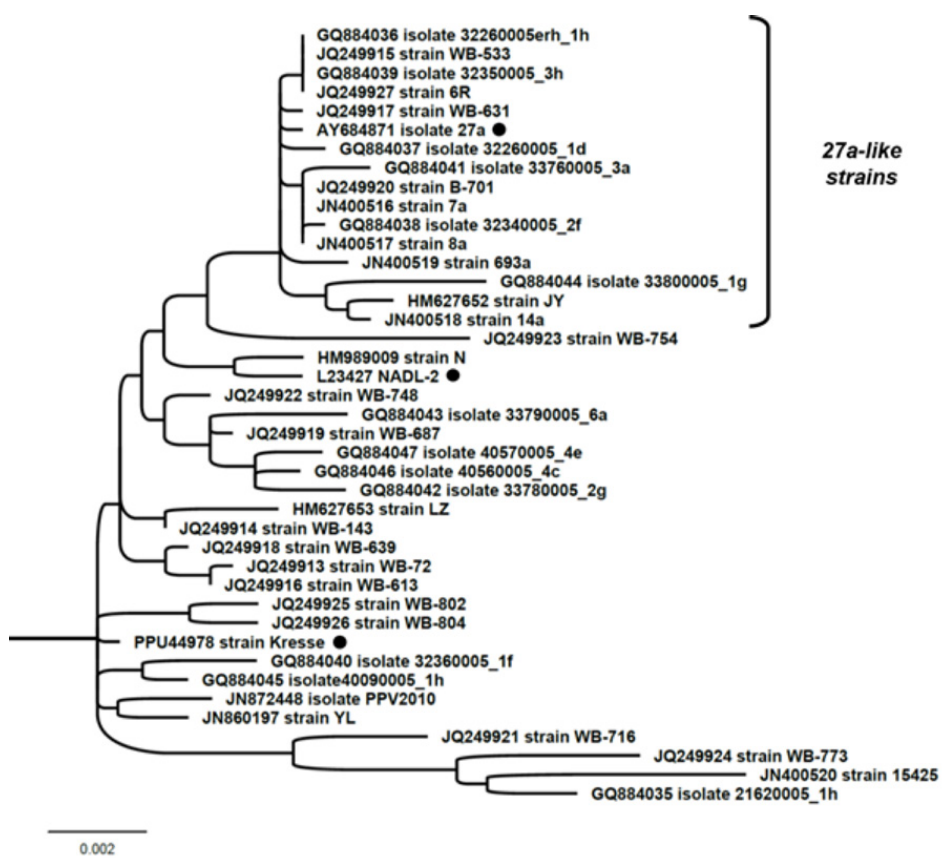

Figure 6.2 PPV sequences phylogenetic tree inferred using the Maximum Likelihood method based on the Hasegawa-Kishino-Yano model. A discrete Gamma distribution was used to model evolutionary rate differences among sites (5 categories). The tree is drawn to scale, with branch lengths measured in the number of substitutions per site. Evolutionary analyses were conducted in MEGA7 (Kumer et al., 2016). The reference strains NADL-2, Kresse and 27a are indicated by black dots. 
35 of gestation) an infection with PPV results in embryonic death and maternal resorption of fetal tissues. From the 35th day of gestation on, fetal organogenesis is mainly complete and ossification of the fetal skeleton begins. PPV infection after this time typically results in fetal death followed by mummification. Finally, after the 70th gestation day, the fetus is able to build an effective immune response and eliminate the virus and fetal infection becomes mainly subclinical. In this last case, the piglet is born with anti-PPV antibodies (Bachmann et al., 1975; Joo et al., 1977; Lenghaus et al., 1978; Mengeling et al., 2000).

Lesions are only evident in embryos or fetuses. Even experimental PPV inoculation in boars, gilts, and sows does not produce macroscopic lesions (Bachmann et al., 1975; Mengeling and Cutlip, 1976; Lenghaus et al., 1978; Mengeling, 1978; Thacker et al., 1987). Macroscopically, the embryonic death followed by resorption of fluids and soft tissues is the most common sequel to PPV infection. The lesions include a variable degree of congestion, oedema and haemorrhage with accumulation of serosanguinous fluids in body cavities. After the death of the fetus, a discoloration of the skin resulting from the bleeding occurs, giving the fetus a dark tonality. Finally, progressive dehydration of tissues leads to the mummification (Fig. 6.3). The placenta can be dehydrated and brown to grey in colour and the extrafetal fluid volume reduced (Joo et al., 1977; Lenghaus et al., 1978).

Microscopic lesions in females include focal accumulation of mononuclear cells adjacent to the endometrium and in deeper layers of the lamina propria and a marked perivascular cuffing of plasma cells and lymphocytes in the brains, spinal cord, and choroid of the eye (Hogg et al., 1977). Sows also had uterine lesions that included extensive cuffing of mononuclear cells around myometrial and endometrial vessels (Lenghaus et al., 1978).

In the fetus, histopathological changes tend to be widespread in the different tissues and the major lesions represent necrosis of cells in developing organ systems (Joo et al., 1977; Lenghaus et al., 1978). Haemorrhages are present in subcutaneous tissues and muscle masses. Necrosis and mineralization are common in the lungs, kidneys, and skeletal muscle,
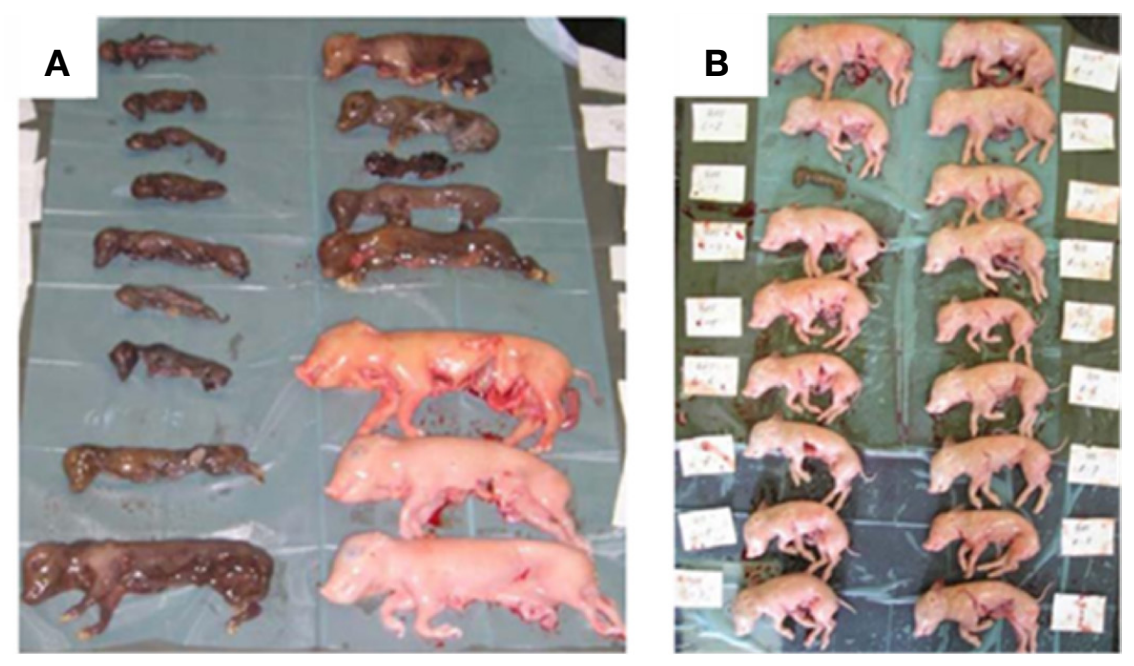

Figure 6.3 Litters of inoculated pregnant sows [with 27a (A) and NADL-2 strains (B)] at the 90th gestational day displaying distinct levels of lesions. The fetuses' position corresponds to their position in the uterus (the most cervical-positioned fetuses at the top) (Zeeuw et al., 2007). 
particularly in the liver and heart (Lenghaus et al., 1978). After the fetuses become immunocompetent, microscopic lesions are primarily endometrial hypertrophy and mononuclear cell infiltration (Hogg et al., 1977; Joo et al., 1977). Meningoencephalitis characterized by perivascular cuffing with proliferating adventitial cells, histiocytes, and a few plasma cells in the grey and white matter of the cerebrum and leptomeninges were also seen in PPVinfected live fetuses delivered late in gestation or in stillborn piglets (Narita et al., 1975; Hogg et al., 1977; Joo et al., 1977).

\section{Diagnostic procedures}

Porcine parvovirus infection may not cause abortions and does not cause clinical signs in adults (Mengeling and Cutlip, 1975). PPV can be strongly considered when females return to oestrus with no apparent reasons or delays in parturition with increased numbers of mummified fetuses and smaller litters, especially in first or second parity females. For these clinical signs, the differential diagnosis should also include Aujeszky's disease, brucellosis, leptospirosis, porcine reproductive and respiratory syndrome (PRRS), toxoplasmosis, nonspecific bacterial uterine infection, and other metabolic and genetic problems.

The material to be submitted to the laboratory to perform the diagnostic should include mummified fetuses and fetal remains. Detection of viral antigen in fetal tissues by immunofluorescence (IF; Fig. 6.4) was a reliable procedure for the diagnosis of PPV (Mengeling and Cutlip, 1975). In the past, the virus detection and titration can be performed by the hemagglutination technique (HA), based on the hemagglutinating activity of PPV against erythrocytes of certain species, e.g. chickens, humans, guinea pigs (Joo et al., 1976). Today, since the virus has a high replication efficiency in renal or testicular swine cells, virus propagation in cell-lines such as ESK (embryonic swine kidney), PK-15 (pig kidney), SK6 (swine kidney), STE (swine testicular epithelioid) and SPEV (swine embryo kidney) is used. Once in these cells, the PPV replication usually causes cytopathic effects, including granulations, irregular shape, slow replication, intra-nuclear inclusions, pyknotic nucleus and consequently cell death (Cartwright et al., 1969; Mengeling, 1972). Due to possible similar cytopathic effects of other viruses or enzymatic effects, virus isolation and titration is often associated with immunofluorescence microscopy (Cartwright et al., 1971; Johnson, 1973).

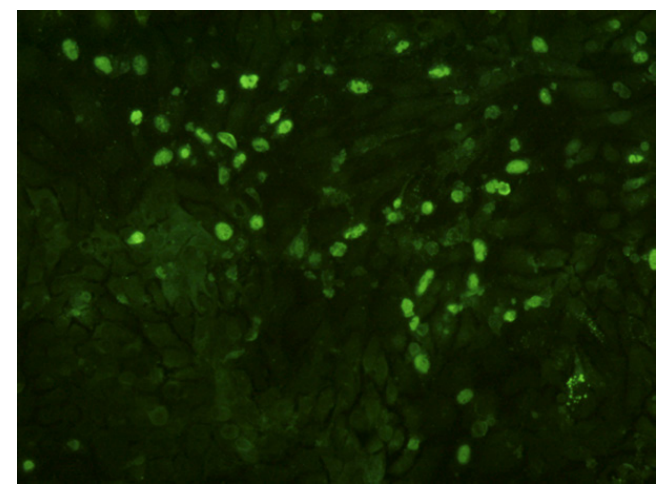

Figure 6.4 Indirect immunofluorescence of PK-15 cells infected with PPV. Positive nuclear fluorescence (green) is evidenced five days post infection. Magnification of 400x. 
More recently, nucleic acid-based techniques can be used for viral detection in clinical samples with a better sensitivity that the other direct techniques. The polymerase chain reaction (PCR) is the most useful technique for the detection of PPV in fetal tissues, semen, and other samples. Numerous PCR protocols (and quantitative PCR methods) have been described (Molitor et al., 1991; Soares et al., 1999; Wilhelm et al., 2006; Chen et al., 2009; Streck et al., 2015b; Yang et al., 2016). These methods are considered to possess higher diagnostic sensitivity and specificity than hemagglutination or virus isolation and are better suited for the detection of PPV in autolysed tissues. However, the likelihood of successful recovery of virus or nucleic acid will depend on the condition of fetal tissues at the time of collection.

Alternatively, serology may be useful for the diagnosis of PPV when fetal tissues are not available or sample is autolysed; however, the high prevalence of PPV in populations often present challenges to the interpretation of results. For these reasons, paired serum samples should be evaluated. As standard method, the haemagglutination inhibition (HI) assay is frequently used for the quantification of PPV specific antibodies. Usually, the serum to be assayed in the $\mathrm{HI}$ test is usually pretreated by heat inactivation $\left(56^{\circ} \mathrm{C}\right.$, for 30 minutes) followed by adsorption with erythrocytes and kaolin (to remove or reduce non-specific inhibitors of haemagglutination) (Mengeling, 1972; Morimoto et al., 1972). Importantly, HI results may be affected by incubation temperature and the source of erythrocytes. Another technique, the enzyme-linked immunosorbent assay (ELISA), can be standardized more easily and is suited to automatization. Moreover, serum does not have to be pre-treated before testing in the ELISA (Hohdatsu et al., 1988; Westenbrink et al., 1989). The ELISA can potentially differentiate vaccinated animals from animals having been infected with PPV. As the currently used inactivated vaccines induce antibodies only against VP proteins and not against the NS proteins, ELISAs that differentiate these two proteins could identify antibodies raised from a natural infection (Madsen et al., 1997; Qing et al., 2006).

\section{Epidemiology}

PPV is considered to be endemic in most of the world. The virus can be found in all pig herd categories, including in boars and fattening pigs. The epidemiology of porcine parvovirus is primarily marked by the high stability of the virus in the environment. That is, PPV can remain infectious for months, and contaminated instruments or stables may therefore be a constant source of infection. The virus can be transported between herds via fomites, for example the clothes, boots, equipment and clothing of farmers from one herd to another. It is also speculated that infected boars can introduce the virus into new herds. There are numerous reports on PPV in the semen of naturally infected boars (Cartwright and Huck, 1967; Ruckerbauer et al., 1978); however, whether PPV is shed in the semen of infected boars or whether PPV in semen represents only a contamination is still unresolved. Importantly, introduction of PPV into a herd does not cause immediate problems if sows are immune through vaccination or natural exposure. Disease occur when there is circulation in a population with new mutants that cannot be completely prevented by vaccination or a lack of vaccination.

Stability of PPV can be evidenced by its resistance to inactivation by ethanol (70\%), quaternary ammonium $(0.05 \%)$ and low concentrations of sodium hypochlorite $(2500 \mathrm{ppm})$ and peracetic acid $(0.2 \%)$. The virus is also heat stable and may resist dry (but not moist) 
heat at $90^{\circ} \mathrm{C}$. The inactivation of PPV should be performed by aldehyde-based disinfectants, higher concentrations of sodium hypochlorite $(25,000 \mathrm{ppm})$ and hydrogen peroxide (7.5\%) (Eterpi et al., 2009).

\section{Control of the virus (including vaccine and antiviral research)}

There is no specific treatment for parvovirosis. General management measures aimed at promoting good health status of the herd should be adopted (Mengeling, 1999). A more practical goal in commercial herds is to maintain herd immunity against PPV. Before the advent of vaccination, intentional infection of gilts to PPV by exposure to virus-contaminated tissues from affected litters before the first breeding was used to control parvovirus. Approaches like this type are unreliable and dangerous because they can result in the dissemination of other pathogens in the population, for example, classical swine fever virus.

The first vaccines developed during the 1970s were made with inactivated virus (Suzuki and Fujisaki, 1976, Joo and Johnson, 1977, Mengeling et al., 1979). A few years later, regular vaccination of breeding sows with these vaccines became a worldwide practice. Currently, PPV vaccines represent cell culture derived virus (usually the non-pathogenic NADL-2 strain) which is chemically inactivated (by formalin, beta-propiolactone or binary ethyleneimine), mixed with oil or aluminium hydroxide as adjuvants and administered parenterally. The use of these vaccines induces antibody titres that can reduce clinical manifestations, but cannot prevent infection (Józwik et al., 2009, Foerster et al., 2016). The vaccination schedules can be adjusted to the animal category. Gilts usually receive the first dose at the age of 170-180 days, or 30 days before insemination. The second dose is usually administered 15 days later. Sows are boosted usually 10-15 days after each farrowing. Boars can be vaccinated as well and boosted yearly.

Modified-live virus vaccines (MLV) could be an alternative for PPV. The use of parvovirus MLVs in carnivores induce a long-lasting immune response that provides protection for several years. For PPV, the few reports on live-vaccines observed transplacental transmission was prevented, but viraemia and shedding of the vaccine strain after vaccination was common (Paul and Mengeling, 1980, 1984). However, the attempts were mainly based on NADL-2 virus as the vaccine virus. To our knowledge, there are no reports of vaccines based on a modified strain.

Furthermore, the occurrence and distribution of new antigenic types have to be watched very closely. It was observed that new mutations in the capsid protein can modify antigenic properties, and may reduce the cross neutralization ability of sera raised against strains commonly used in commercial vaccines (Zeeuw et al., 2007; Streck et al., 2013, 2015a). New vaccines that induce a long-lasting immunity and cover all the dominant virus strains circulating in pig populations are needed to overcome currently observed putative vaccination failures.

\section{The emergence of novel parvoviruses}

In other animal species, such as humans and canines, parvoviruses are represented by viruses classified in two or more genera. In pigs, only in the genus protoparvovirus a parvovirus, commonly known as porcine parvovirus (PPV) was established, however, in the last decade, with the development of novel molecular techniques several new (proto)parvoviruses have 
been identified. The first newly identified parvovirus was identified in sera during a hepatitis E virus investigation in Myanmar (Hijisaka et al., 2001), originally termed as porcine parvovirus 2 (PPV2). More recently, a high prevalence of this virus could be obtained in lung samples. Viral positivity could also be detected in faecal samples obtained from pigs of different age groups, and in sera or thoracic fluids obtained from neonatal pigs (Xiao et al., 2013).

In 2008, a virus closely related to the human parvovirus 4 was found in slaughtered pigs in Hong Kong (Lau et al., 2008). Currently, several sequences with high homology (>98\% DNA similarity) exist in the DNA databanks under different names, including porcine hokovirus, PARV4-like and porcine parvovirus 4 . The virus has already been detected worldwide (Adlhoch et al., 2010; Cadar et al., 2011; Pan et al., 2012; Xiao et al., 2012) and its usually nominated porcine parvovirus 3 (PPV3).

In 2010, another parvovirus was found in the USA in porcine circovirus-associated disease-affected pigs and designated as porcine parvovirus 4 (PPV4) (Cheung et al., 2010). After that, PPV4 was already detected in several continents (Huang et al., 2011, Zhang et al., 2011; Cságola et al., 2012; Cadar et al., 2013; Ndze et al., 2013). Thereafter, during an initial investigation of the PPV4 prevalence in U.S. pigs, a novel PPV, named PPV5, was identified and showed the closest relationship to PPV4 (Fig. 6.5) (Xiau et al., 2013). Another closest related parvovirus to PP4 and PPV5 was initially identified from aborted pig fetuses in China and termed PP6 (Ni et al., 2014).

Finally, in pigs with postweaning multisystemic wasting syndrome (PMWS), a porcine bocavirus ( $\mathrm{PBoV}$, classified in the genus Bocaparvovirus) was identified in lymph nodes (Blomström et al., 2009) and subsequently other novel bocaviruses named PBoV2, PBoV3,

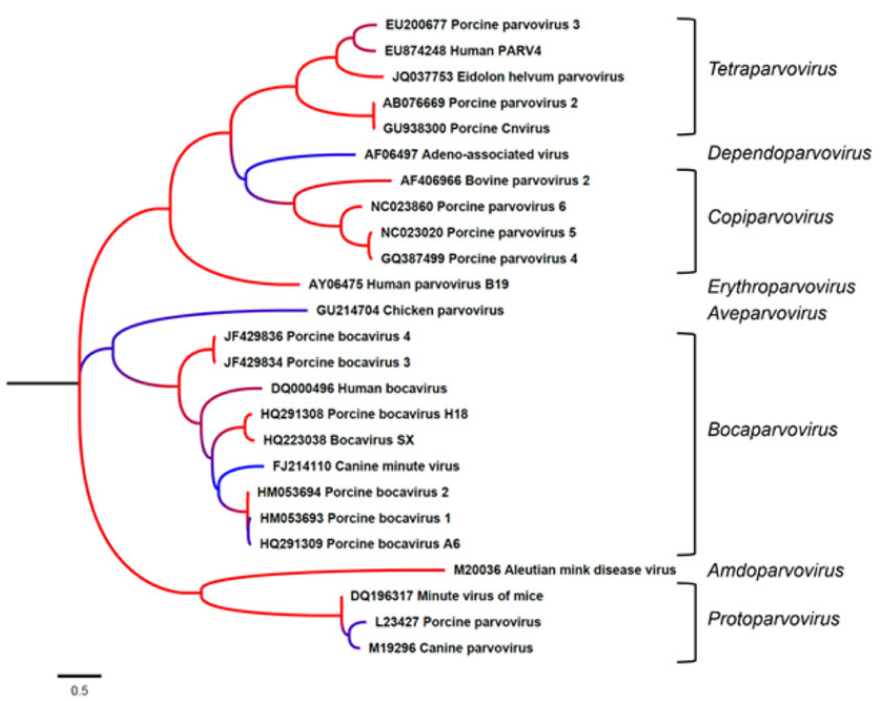

Figure 6.5 Phylogenetic tree of the porcine parvoviruses sequences inferred using the using the Maximum Likelihood method. The confidence was measured using the bootstrap method inferred from 1000 replicates and it is displayed with colour gradient $(1=$ red; $0=$ blue). A discrete Gamma distribution was used to model evolutionary rate differences among sites ( 5 categories). The tree is drawn to scale, with branch lengths measured in the number of substitutions per site. Evolutionary analyses were conducted in MEGA7 (Kumer et al., 2016). 
Table 6.1 The formerly used nomenclature for the species and the current classification based upon the International Committee on Taxonomy of Viruses (ICTV)

\begin{tabular}{ll}
\hline Virus & ICTV current classification \\
\hline Porcine parvovirus 1 & Ungulate protoparvovirus 1 \\
Porcine parvovirus 2 & Not yet classified \\
Porcine parvovirus 3, porcine hokovirus, PARV4-like & Ungulate tetraparvovirus 2 \\
Porcine Cnvirus & Ungulate tetraparvovirus 3 \\
Porcine parvovirus 4 & Ungulate copiparvovirus 2 \\
Porcine parvovirus 5 & Not yet classified \\
Porcine parvovirus 6 & Not yet classified \\
Porcine bocaviruses & Porcine bocaparvovirus 2, 3, 4 and 5 \\
\hline
\end{tabular}

Table adapted from Streck et al. (2015a).

PBoV4, 6V and 7V followed (Cheng et al., 2010; Zhai et al., 2010; Zeng et al., 2011; Yang et al., 2012).

Despite the epidemiological studies, any possible association with clinical signs of these newly identified PPV or PBoV remains unclear. Although, they may possess a potential public health interest due to their genetic similarity with human parvoviruses. The current classification based upon the International Committee on Taxonomy of Viruses for these novel viruses is available in Table 6.1.

\section{References}

Adlhoch, C., Kaiser, M., Ellerbrok, H., and Pauli, G. (2010). High prevalence of porcine hokovirus in German wild boar populations. Virol. J. 7, 171. https://doi.org/10.1186/1743-422X-7-171

Bachmann, P.A., Sheffy, B.E., and Vauhan, J.T. (1975). Experimental in utero infection of fetal pigs with a porcine parvovirus. Infect. Immun. 12, 455-460.

Blomström, A.L., Belák, S., Fossum, C., McKillen, J., Allan, G., Wallgren, P., and Berg, M. (2009). Detection of a novel porcine boca-like virus in the background of porcine circovirus type 2 induced postweaning multisystemic wasting syndrome. Virus Res. 146, 125-129. https://doi.org/10.1016/j. virusres.2009.09.006

Boisvert, M., Fernandes, S., and Tijssen, P. (2010). Multiple pathways involved in porcine parvovirus cellular entry and trafficking toward the nucleus. J. Virol. 84, 7782-7792. https://doi.org/10.1128/ JVI.00479-10

Brown, T.T., Paul, P.S., and Mengeling, W.L. (1980). Response of conventionally raised weanling pigs to experimental infection with a virulent strain of porcine parvovirus. Am. J. Vet. Res. 41, 1221-1224.

Cadar, D., Cságola, A., Kiss, T., and Tuboly, T. (2013). Capsid protein evolution and comparative phylogeny of novel porcine parvoviruses. Mol. Phylogenet. Evol. 66, 243-253. https://doi.org/10.1016/j. ympev.2012.09.030

Cadar, D., Cságola, A., Lorincz, M., Tombácz, K., Spînu, M., and Tuboly, T. (2011). Distribution and genetic diversity of porcine hokovirus in wild boars. Arch. Virol. 156, 2233-2239. https://doi.org/10.1007/ s00705-011-1125-6

Cartwright, S.F., and Huck, R.A. (1967). Viruses isolated in association with herd infertility, abortions and stillbirths in pigs. Vet. Rec. 81, 196-197.

Cartwright, S.F., Lucas, M., and Huck, R.A. (1969). A small haemagglutinating porcine DNA virus. I. Isolation and properties. J. Comp. Pathol. 79, 371-377.

Chapman, M.S., and Rossmann, M.G. (1993). Structure, sequence, and function correlations among parvoviruses. Virology 194, 491-508. https://dx.doi.org/10.1006/viro.1993.1288

Chen, H.Y., Li, X.K., Cui, B.A., Wei, Z.Y., Li, X.S., Wang, Y.B., Zhao, L., and Wang, Z.Y. (2009). A TaqManbased real-time polymerase chain reaction for the detection of porcine parvovirus. J. Virol. Methods 156, 84-88. https://doi.org/10.1016/j.jviromet.2008.10.029 
Cheng, W.X., Li, J.S., Huang, C.P., Yao, D.P., Liu, N., Cui, S.X., Jin, Y., and Duan, Z.J. (2010). Identification and nearly full-length genome characterization of novel porcine bocaviruses. PLOS ONE 5, e13583. https://doi.org/10.1371/journal.pone.0013583

Cheung, A.K., Wu, G., Wang, D., Bayles, D.O., Lager, K.M., and Vincent, A.L. (2010). Identification and molecular cloning of a novel porcine parvovirus. Arch. Virol. 155, 801-806. https://doi.org/10.1007/ s00705-010-0646-8

Cotmore, S.F., and Tattersall, P. (2006). Structure and organization of the viral genome. In Parvoviruses, Kerr, J., Cotmre, S.F., Bloom, M.E., Linden, R.M. Parrish, C.R., eds (Hodder Arnold, London), pp. 72-94.

Cságola, A., Lőrincz, M., Cadar, D., Tombácz, K., Biksi, I., and Tuboly, T. (2012). Detection, prevalence and analysis of emerging porcine parvovirus infections. Arch. Virol. 157, 1003-1010. https://doi. org/10.1007/s00705-012-1257-3

Eterpi, M., McDonnell, G., and Thomas, V. (2009). Disinfection efficacy against parvoviruses compared with reference viruses. J. Hosp. Infect. 73, 64-70. https://doi.org/10.1016/j.jhin.2009.05.016

Farr, G.A., Zhang, L.G., and Tattersall, P. (2005). Parvoviral virions deploy a capsid-tethered lipolytic enzyme to breach the endosomal membrane during cell entry. Proc. Natl. Acad. Sci. U.S.A. 102, 17148-17153. https://dx.doi.org/10.1073/pnas.0508477102.

Foerster, T., Streck, A.F., Speck, S., Selbitz, H.J., Lindner, T., and Truyen, U. (2016). An inactivated wholevirus porcine parvovirus vaccine protects pigs against disease but does not prevent virus shedding even after homologous virus challenge. J. Gen. Virol. 97, 1-6. https://doi.org/10.1099/jgv.0.000446

Hijikata, M., Abe, K., Win, K.M., Shimizu, Y.K., Keicho, N., and Yoshikura, H. (2001). Identification of new parvovirus DNA sequence in swine sera from Myanmar. Jpn. J. Infect. Dis. 54, 244-245.

Hogg, G.G., Lenghaus, C., and Forman, A.J. (1977). Experimental porcine parvovirus infection of foetal pigs resulting in abortion, histological lesions and antibody formation. J. Comp. Pathol. 87, 539-549. https://doi.org/10.1016/0021-9975(77)90060-3

Hohdatsu, T., Baba, K., Ide, S., Tsuchimoto, M., Nagano, H., Yamagami, T., Yamagishi, H., Fujisaki, Y., and Matumoto, M. (1988). Detection of antibodies against porcine parvovirus in swine sera by enzymelinked immunosorbent assay. Vet. Microbiol. 17, 11-19.

Huang, L., Zhai, S.L., Cheung, A.K., Zhang, H.B., Long, J.X., and Yuan, S.S. (2010). Detection of a novel porcine parvovirus, PPV4, in Chinese swine herds. Virol. J. 7, 333. https://doi.org/10.1186/1743422X-7-333

Johnson, R.H. (1973). Isolation of swine parvovirus in Queensland. Aust. Vet. J. 49, 257-259. https:// dx.doi.org/10.1111/j.1751-0813.1973.tb06768.x

Joo, H.S., Donaldson-Wood, C.R., Johnson, R.H., and Campbell, R.S. (1977). Pathogenesis of porcine parvovirus infection: Pathology and immunofluorescence in the foetus. J. Comp. Pathol. 87, 383-391.

Joo, H.S., Donaldson-Wood, C.R., and Johnson, R.H. (1976). Letter: Rapid diagnostic techniques for detection of porcine parvovirus infection in mummified foetuses. Aust. Vet. J. 52, 51-52.

Joo, H.S., and Johnson, R.H. (1977). Serological responses in pigs vaccinated with inactivated porcine parvovirus. Aust. Vet. J. 53, 550-552.

Jóźwik, A., Manteufel, J., Selbitz, H.J., and Truyen, U. (2009). Vaccination against porcine parvovirus protects against disease, but does not prevent infection and virus shedding after challenge infection with a heterologous virus strain. J. Gen. Virol. 90, 2437-2441. https://dx.doi.org/2441.10.1099/ vir.0.012054-0

Kumar, S., Stecher, G., and Tamura, K. (2016). MEGA7: Molecular evolutionary genetics analysis version 7.0 for bigger datasets. Mol. Biol. Evol. 33, 1870-1874. https://doi.org/10.1093/molbev/msw054

Lau, S.K., Woo, P.C., Tse, H., Fu, C.T., Au, W.K., Chen, X.C., Tsoi, H.W., Tsang, T.H., Chan, J.S., Tsang, D.N., Li, K.S., Tse, C.W., Ng, T.K., Tsang, O.T., Zheng, B.J., Tam, S., Chan, K.H., Zhou, B., Yuen, K.Y. (2008). Identification of novel porcine and bovine parvoviruses closely related to human parvovirus 4. J. Gen. Virol. 89, 1840-1848. https://dx.doi.org/10.1099/vir.0.2008/000380-0

Lawson, J.R. (1961). Infectious infertility of swine. In Reports of the Meeting of the Expert Panel of Livestock Infertility (Rome), p. 67.

Lenghaus, C., Forman, A.J., and Hale, C.J. (1978). Experimental infection of 35, 50 and 60 day old pig foetuses with porcine parvovirus. Aust. Vet. J. 54, 418-422.

Madsen, E.S., Madsen, K.G., Nielsen, J., Jensen, M.H., Lei, J.C., and Have, P. (1997). Detection of antibodies against porcine parvovirus nonstructural protein NS1 may distinguish between vaccinated and infected pigs. Vet. Microbiol. 54, 1-16. 
Mahnel, H. (1965). Virus-like particles from hog cholera infected tissue cultures and demonstrated in the electron microscope. Proceedings of the FAO/OIE meeting on hog cholera and African swine fever (Rome, Italy).

Mayr, A., and Mahnel, H. (1964). [Cultivation of hog cholera virus in pig kidney cultures with cytopathogenic effect.] Zentralbl. Bakteriol. Orig. 195, 157-166.

Mengeling, W.L. (1972). Porcine parvovirus: Properties and prevalence of a strain isolated in the United States. Am. J. Vet. Res. 33, 2239-2248.

Mengeling, W.L. (1978). Prevalence of porcine parvovirus-induced reproductive failure: An abattoir study. J. Am. Vet. Med. Assoc. 172, 1291-1294.

Mengeling, W.L., Brown, T.T., Paul, P.S., and Gutekunst, D.E. (1979). Efficacy of an inactivated virus vaccine for prevention of porcine parvovirus-induced reproductive failure. Am. J. Vet. Res. 40, 204-207.

Mengeling, W.L., and Cutlip, R.C. (1975). Pathogenesis of in utero infection: Experimental infection of five-week-old porcine fetuses with porcine parvovirus. Am. J. Vet. Res. 36, 1173-1177.

Mengeling, W.L., and Cutlip, R.C. (1976). Reproductive disease experimentally induced by exposing pregnant gilts to porcine parvovirus. Am. J. Vet. Res. 37, 1393-1400.

Mengeling, W.L., Lager, K.M., and Vorwald, A.C. (2000). The effect of porcine parvovirus and porcine reproductive and respiratory syndrome virus on porcine reproductive performance. Anim. Reprod. Sci. 60-61, 199-210.

Molitor, T.W., Oraveerakul, K., Zhang, Q.Q. Choi, C.S., and Ludemann, L.R. (1991). Polymerase chain reaction (PCR) amplification for the detection of porcine parvovirus. J. Virol. Methods 32, 201-211.

Morimoto, T., Fujisaki, Y., Ito, Y., and Tanaka, Y. (1972). Biological and physicochemical properties of porcine parvovirus recovered from stillborn piglets. Natl. Inst. Anim. Health Q. 12, 137-144.

Narita, M., Inui, S., Kawakami, Y., Kitamura, K., and Maeda, A. (1975). Histopathological changes of the brain in swine fetuses naturally infected with procine parvovirus. Natl. Inst. Anim. Health Q. 15, 24-28.

Ndze, V.N., Cadar, D., Cságola, A., Kisfali, P., Kovács, E., Farkas, S., Ngu, A.F., Esona, M.D., Dán, Á., Tuboly, T., et al. (2013). Detection of novel porcine bocaviruses in fecal samples of asymptomatic pigs in Cameroon. Infect. Genet. Evol. 17, 277-282. https://doi.org/10.1016/j.meegid.2013.03.006

Ni, J., Qiao, C., Han, X., Han, T., Kang, W., Zi, Z., Cao, Z., Zhai, X., and Cai, X. (2014). Identification and genomic characterization of a novel porcine parvovirus (PPV6) in China. Virol. J. 11, 203. https://doi. org/10.1186/s12985-014-0203-2

Pan, Y., Zeng, Q. Zhu, C., Hua, X., Wang, M., Pan, K., and Cui, L. (2012). Frequency and characterization of porcine hokovirus (PHoV) in domestic pigs in eastern China. Arch. Virol. 157, 1785-1788. https:// doi.org/10.1007/s00705-012-1350-7

Paul, P.S., Mengeling, W.L., and Brown, T.T. (1979). Replication of porcine parvovirus in peripheral blood lymphocytes, monocytes, and peritoneal macrophages. Infect. Immun. 25, 1003-1007.

Paul, P.S., and Mengeling, W.L. (1980). Evaluation of a modified live-virus vaccine for the prevention of porcine parvovirus-induced reproductive disease in swine. Am. J. Vet. Res. 41, 2007-2011.

Paul, P.S., and Mengeling, W.L. (1984). Oronasal and intramuscular vaccination of swine with a modified live porcine parvovirus vaccine: Multiplication and transmission of the vaccine virus. Am. J. Vet. Res. 45, 2481-2485.

Paul, P.S., Mengeling, W.L., and Brown, T.T. (1980). Effect of vaccinal and passive immunity on experimental infection of pigs with porcine parvovirus. Am. J. Vet. Res. 41, 1368-1371.

Qing, L., Lv, J., Li, H., Tan, Y., Hao, H., Chen, Z., Zhao, J., and Chen, H. (2006). The recombinant nonstructural polyprotein NS1 of porcine parvovirus (PPV) as diagnostic antigen in ELISA to differentiate infected from vaccinated pigs. Vet. Res. Commun. 30, 175-190. https://doi.org/10.1007/ s11259-006-3212-9

Rasbech, N.O. (1969). A review of the causes of reproductive failure in swine. Br. Vet. J. 125, 599-616.

Rhode, S.L. (1973). Replication process of the parvovirus H-1. I. Kinetics in a parasynchronous cell system. J. Virol. 11, 856-861.

Ruckerbauer, G.M., Dulac, G.C., and Boulanger, P. (1978). Demonstration of parvovirus in Canadian swine and antigenic relationships with isolates from other countries. Can. J. Comp. Med. 42, 278-285.

Siegl, G. (1976). The parvoviruses. In Virology Monographs, Gard, S., and Hallauer, C., eds (SpringerVerlag, Wien, New York), vol. 15, pp. 47-52.

Simpson, A.A., Hébert, B., Sullivan, G.M., Parrish, C.R., Zádori, Z., Tijssen, P., and Rossmann, M.G. (2002). The structure of porcine parvovirus: Comparison with related viruses. J. Mol. Biol. 315, 1189-1198. https://doi.org/10.1006/jmbi.2001.5319 
Soares, R.M., Durigon, E.L., Bersano, J.G., and Richtzenhain, L.J. (1999). Detection of porcine parvovirus DNA by the polymerase chain reaction assay using primers to the highly conserved nonstructural protein gene, NS-1. J. Virol. Methods 78, 191-198. https://doi.org/10.1016/S0166-0934(98)00177-3

Streck, A.F., Bonatto, S.L., Homeier, T., Souza, C.K., Gonçalves, K.R., Gava, D., Canal, C.W., and Truyen, U. (2011). High rate of viral evolution in the capsid protein of porcine parvovirus. J. Gen. Virol. 92, 2628-2636. https://doi.org/ 10.1099/vir.0.033662-0

Streck, A.F., Canal, C.W., and Truyen, U. (2015a). Molecular epidemiology and evolution of porcine parvoviruses. Infect. Genet. Evol. 36, 300-306.

Streck, A.F., Hergemöller, F., Rüster, D., Speck, S., and Truyen, U. (2015b). A TaqMan qPCR for quantitation of Ungulate protoparvovirus 1 validated in several matrices. J. Virol. Methods 218, 46-50. https://doi. org/10.1016/j.jviromet.2015.03.003

Streck, A.F., Homeier, T., Foerster, T., and Truyen U. (2013). Population dynamics and in vitro antibody pressure of porcine parvovirus indicate a decrease in variability. Arch. Virol. 158, 1173-1180. https:// dx.doi.org/10.1099/vir.0.052555-0

Suzuki, H., and Fujisaki, Y. (1976). Immunizing effects of inactivated porcine parvovirus vaccine on piglets. Bull. Nat. Inst. Anim. Health 72, 17-23.

Thacker, B.J., Joo, H.S., Winkelman, N.L., Leman, A.D., and Barnes, D.M. (1987). Clinical, virologic, and histopathologic observations of induced porcine parvovirus infection in boars. Am. J. Vet. Res. 48, $763-767$.

Truyen, U., and Streck, A.F. (2012). Porcine parvovirus. In Diseases of Swine, 10th edn, Zimmerman, J., Karriker, L., Ramirez, A., Schwartz, K., and Stevenson, G., eds (John Wiley \& Sons, Oxford), pp. 447-455.

Vihinen-Ranta, M., Wang, D., Weichert, W.S., and Parrish, C.R. (2002). The VP1 N-terminal sequence of canine parvovirus affects nuclear transport of capsids and efficient cell infection. J. Virol. 76, 1884-1891. https://dx.doi.org/10.1128/JVI.76.4.1884-1891.2002

Westenbrink, F., Veldhuis, M.A., and Brinkhof, J.M. (1989). An enzyme-linked immunosorbent assay for detection of antibodies to porcine parvovirus. J. Virol. Methods 23, 169-178.

Wilhelm, S., Zimmermann, P., Selbitz, H.J., and Truyen, U. (2006). Real-time PCR protocol for the detection of porcine parvovirus in field samples. J. Virol. Methods 134, 257-260.

Yang, Y., Qin, X., Zhang, W., Li, Y., and Zhang, Z. (2016). Rapid and specific detection of porcine parvovirus by isothermal recombinase polymerase amplification assays. Mol. Cell. Probes 30, 300-305.

Yang, W.Z., Yu, J.M., Li, J.S., Cheng, W.X., Huang, C.P., and Duan, Z.J. (2012). Genome characterization of a novel porcine bocavirus. Arch. Virol. 157, 2125-2132. https://doi.org/10.1007/s00705-012-1407-7

Zádori, Z., Szelei, J., and Tijssen, P. (2005). SAT: A late NS protein of porcine parvovirus. J. Virol. 79, 13129-13138.https://dx.doi.org/10.1128/JVI.79.20.13129-13138.2005

Zeng, S., Wang, D., Fang, L., Ma, J., Song, T., Zhang, R., Chen, H., and Xiao, S. (2011). Complete coding sequences and phylogenetic analysis of porcine bocavirus. J. Gen. Virol. 92, 784-788. https://dx.doi. org/10.1099/vir.0.028340-0

Zeeuw, E.J.L., Leinecker, N., Herwig, V., Selbitz, H.J., and Truyen, U. (2007). Study of the virulence and cross-neutralization capability of recent porcine parvovirus field isolates and vaccine viruses in experimentally infected pregnant gilts. J. Gen. Virol. 88, 420-427. https://dx.doi.org/10.1099/ vir.0.82302-0

Zhai, S., Yue, C., Wei, Z., Long, J., Ran, D., Lin, T., Deng, Y., Huang, L., Sun, L., Zheng, H., et al. (2010). High prevalence of a novel porcine bocavirus in weanling piglets with respiratory tract symptoms in China. Arch. Virol. 155, 1313-1317. https://doi.org/10.1007/s00705-010-0698-9

Zhang, H.B., Huang, L., Liu, Y.J., Lin, T., Sun, C.Q. Deng, Y., Wei, Z.Z., Cheung, A.K., Long, J.X., and Yuan, S.S. (2011). Porcine bocaviruses: Genetic analysis and prevalence in Chinese swine population. Epidemiol. Infect. 139, 1581-1586. https://doi.org/10.1017/S0950268811000847

Zhao, X., Xiang, H., Bai, X., Fei, N., Huang, Y., Song, X., Zhang, H., Zhang, L., and Tong, D. (2016). Porcine parvovirus infection activates mitochondria-mediated apoptotic signaling pathway by inducing ROS accumulation. Virol. J. 13, 26. https://doi.org/10.1186/s12985-016-0480-z

Xiao, C.T., Giménez-Lirola, L.G., Halbur, P.G., and Opriessnig, T. (2012). Increasing porcine PARV4 prevalence with pig age in the U.S. pig population. Vet. Microbiol. 160, 290-296. https://doi. org/10.1016/j.vetmic.2012.05.038

Xiao, C.T., Gerber, P.F., Giménez-Lirola, L.G., Halbur, P.G., and Opriessnig, T. (2013). Characterization of porcine parvovirus type 2 (PPV2) which is highly prevalent in the USA. Vet. Microbiol. 161, 325-330. https://doi.org/10.1016/j.vetmic.2012.07.038 
